\title{
Effect of cobalt on growth, pigments and the photosynthetic electron transport in Monoraphidium minutum and Nitzchia perminuta
}

\author{
M.M. El-Sheekh*, A.H. El-Naggar, M.E.H. Osman and E. El-Mazaly
}

Department of Botany, Faculty of Science, Tanta University, Egypt; *Corresponding author: msheekh@dec1.tanta.edu.eg Received: 30/08/2003, Accepted: 27/10/2003

The unicellular green alga Monoraphidium minutum and the diatom Nitzschia perminuta were cultured under different concentrations of $\mathrm{Co}^{2+}$. Growth and pigment content were slightly increased at low concentrations and inhibited by high $\mathrm{Co}^{2+}$ concentrations. The results concerning the effect of different concentrations of $\mathrm{Co}^{2+}$ on photosynthetic $\mathrm{O}_{2}$ evolution showed a reduction in the amount of $\mathrm{O}_{2}$ evolved by each alga in response to increasing $\mathrm{Co}^{2+}$ concentrations. However, an increase in $\mathrm{O}_{2}$ evolution for both M. minutum and $N$. perminuta was observed at relatively low $\mathrm{Co}^{2+}$ concentrations. Photosynthetic electron transport in M. minutum was more sensitive to $\mathrm{Co}^{2+}$ toxicity than in $N$. perminuta. On the other hand, the effect of the heavy metal on respiration showed that higher $\mathrm{Co}^{2+}$ concentrations were inhibitory to $\mathrm{O}_{2}$ uptake by the two algal species. Low $\mathrm{Co}^{2+}$ concentrations stimulated $\mathrm{O}_{2}$ uptake by M. minutum throughout the experimental period. However, in N. perminuta, different concentrations of $\mathrm{Co}^{2+}$ led to a reduction of $\mathrm{O}_{2}$ uptake. To localize the action site of $\mathrm{Co}^{2+}$ in the photosynthetic electron transport chain, the fluorescence induction technique was carried out. According to the results obtained, the inhibitory action of $\mathrm{Co}^{2+}$ is located on the acceptor side of PSII for both M. minutum and N. perminuta.

Key words: cobalt, diatoms, green algae, pigments, photosynthesis.

Efeito do cobalto no crescimento, pigmentos e transporte de elétrons na fotossíntese em Monoraphidium minutum e Nitzchia perminuta: A alga unicelular verde Monoraphidium minutum e a diatomácea Nitzschia perminuta foram cultivadas sob diferentes concentrações de $\mathrm{Co}^{2+}$. O crescimento e o conteúdo de pigmentos foram pouco aumentados em baixas e inibidos em altas concentrações de $\mathrm{Co}^{2+}$. Para ambas as algas, os resultados referentes às concentrações de $\mathrm{Co}^{2+}$ na liberação de $\mathrm{O}_{2}$ fotossintético mostraram redução na quantidade de $\mathrm{O}_{2}$ liberado à medida que se aumentou a concentração de $\mathrm{Co}^{2+}$. No entanto, aumento na liberação de $\mathrm{O}_{2}$ foi observado também para as duas algas em baixas concentrações de $\mathrm{Co}^{2+}$. $\mathrm{O}$ transporte de elétrons na fotossíntese em M. minutum foi mais sensível à toxicidade causada por $\mathrm{Co}^{2+}$ que em N. perminuta. Por outro lado, o efeito desse metal pesado sobre a respiração mostrou que maiores concentrações de $\mathrm{Co}^{2+}$ foram inibitórias para a absorção de $\mathrm{O}_{2}$ nas duas algas. Baixas concentrações de $\mathrm{Co}^{2+}$ estimularam a absorção de $\mathrm{O}_{2}$ em M. minutum. Porém, diferentes concentrações de $\mathrm{Co}^{2+}$ levaram à redução da absorção de $\mathrm{O}_{2}$ em $N$. perminuta. Para identificar o local de ação de $\mathrm{Co}^{2+}$ na cadeia de transporte de elétrons na fotossíntese, utilizou-se a técnica de indução de fluorescência. De acordo com os resultados, a ação inibitória do $\mathrm{Co}^{2+}$ está localizada no lado aceptor do PSII para ambas as algas.

Palavras-chave: alga verde, cobalto, diatomácea, fotossíntese, pigmentos.

\section{INTRODUCTION}

Heavy metals are prevalent in municipal and industrial effluents; they modify the structure and productivity of aquatic ecosystems (Magdaleno et al., 1997). Irrigated agriculture and industrial activity where a lack of conditions prevails for the control and safe disposal of wastes are two important sources of pollution (Custodio, 1992). From a biological point of view, heavy metals can be divided into two categories: essential 
and non-essential (Reddy and Prasad, 1990). However, essential heavy metals have even been reported to be toxic at high concentrations. For example, some heavy metals including copper, zinc, nickel and chromium, are essential for growth at very low concentrations but toxic at slightly levels (Gadd and Griffiths, 1978; Reed and Gadd, 1989). As indicated by Czerpak et al. (1994), the concentration $5 \times 10^{-6}$ $10^{-5}$ mol. $\mathrm{L}^{-1} \mathrm{Co}^{2+}$ exerted maximal stimulatory effect on Chlorella pyrenoidosa cells at the exponential growth phase in terms of fresh weight (150-160\% increase), dry weight (50$60 \%$ increase), chlorophylls $a$ and $b$ (45-65\% increase), total carotenoids (55-65\% increase), water-soluble proteins (19$20 \%$ increase) and monosaccharides content (55-60\% increase), when compared to the control culture. Lustigman et al. (1995) studied the effect of $\mathrm{Co}^{2+}$ on Chlamydomonas reinhardtii. They observed reduction of growth at $10 \mathrm{ppm}$ $\mathrm{Co}^{2+}$ and without change in the morphology of the cells or $\mathrm{pH}$. At $20 \mathrm{ppm} \mathrm{Co}{ }^{2+}$, on the other hand, growth was considerably reduced compared to the control and the colour of the organism became paler and the cells clumped. In addition, the $\mathrm{pH}$ value was lower compared to the $\mathrm{pH}$ of the control at the end of experimental period. Lu et al. (2000) demonstrated that chlorophyll fluorescence analysis could be a useful physiological tool to assess early stages of change in photosynthetic performance of algae in response to heavy metal pollution.

Attempts have been made to identify the site of inhibition for $\mathrm{Co}^{2+}$ in the PSII driven electron transport chain. $\mathrm{Co}^{2+}$ seems to have a direct effect on P680 (Tripathy et al., 1981, 1983; El-Sheekh and Hammouda, 1992). Miyachi et al. (1996) measured quantum requirements of photosynthetic $\mathrm{O}_{2}$ evolution at $679 \mathrm{~nm}$, fluorescence emission spectra at liquid nitrogen temperature and fluorescence induction kinetics in the presence of DCMU, in the cyanobacteria Anabaena variabilis M3, Anabaena variabilis ATCC and Anacystis nidulans R2, each grown under low or high $\mathrm{Co}^{2+}$ conditions. Low $\mathrm{Co}^{2+}$ grown cells of the cyanobacteria showed a higher quantum requirement of photosynthetic $\mathrm{O}_{2}$ evolution together with a higher ratio of F710-740 to F680-700 fluorescence and a lower variable fluorescence in the presence of DCMU compared with high $\mathrm{Co}^{2+}$ grown cells. These findings indicate a change in excitation energy distribution in favour of photosystem I. This might also suggest an enhancement in ATP formation caused by cyclic electron flow, which in turn provokes dissolved inorganic carbon accumulation in these low $\mathrm{Co}^{2+}$ grown cells.
Unlike higher plants, cyanobacteria can adapt to changes in the nutritional status and other environmental changes quite readily (Reuter and Muller, 1993). Growth of Synechocystis PCC 6803 cells in 10 mmol.L-1 $\mathrm{CoCl}_{2}$ stimulates the PSII electron transport rates (Tiwari and Mohanty, 1993). Tiwari and Mohanty (1996) suggested that supplementation of 10 mmol.L-1 $\mathrm{CoCl}_{2}$ to the normal growth medium of Synechocystis PCC 6803 causes multiple changes involving a small increase in PSII to PSI ratio, enhanced funneling of energy to PSII and an increase in PSI electron transport, together with decreased PSI cross section and a reduction in the intersystem pool size. The cumulative effects of these alterations cause stimulation in electron transport and $\mathrm{O}_{2}$ evolution. This report concerns a study of the effect of $\mathrm{Co}^{2+}$ on growth, pigment content, and photosynthesis of the fresh water algae Monoraphidium minutum and Nitzschia perminuta as well as the localization of the site of $\mathrm{Co}^{2+}$ inhibition in photosynthetic electron transport chain.

\section{MATERIAL AND METHODS}

Isolation and purification of the algae: M. minutum and N. perminuta were isolated from fresh water samples collected from the River Nile. One single cell from each colony was isolated, transferred to fresh solid medium and subjected to repeated subculturing on fresh solid media before transfer to sterilized liquid nutrient media.

Nutrient solution and Culture technique: Kuhl medium (Kuhl, 1962) was used for cultivation of M. minutum and Allen's and Stanier (1968) medium used for growth of $N$. perminuta. The culture illumination was provided by fluorescent tube lamps giving a light intensity of 120 watts. $\mathrm{m}^{-2}$. The cultures were supplied with sterilized dry air $(97 \%)$ and $\mathrm{CO}_{2}(97 \%$ : $3 \%, v / v)$.

Determination of the optical density: Growth was followed by measuring the optical density of the green algal suspension at $560 \mathrm{~nm}$, as recommended by Wetherel (1961). On the other hand, the optical density of $N$. perminuta was measured at $750 \mathrm{~nm}$ as cited in Sriharan et al. (1990).

Estimation of pigments: The spectrophotometric method recommended by McKinney (1941), which is suitable for microalgae, was used to estimate chlororphyll $a$, chlorophyll $b$ and carotenoids. 
Measurements of photosynthetic activity $\left(\mathrm{O}_{2}\right.$ evolution) and respiration $\left(\mathrm{O}_{2}\right.$ uptake): The photosynthetic activity was measured polarographically as $\mathrm{O}_{2}$ evolution using a Clarktype electrode (YSI, model 53). The actinic white light was obtained from a $150 \mathrm{~W}$ tungsten lamp.

Fluorescence measurements: Algal cells equivalent to 5 $\mathrm{mg} \cdot \mathrm{ml}^{-1}$ of chlororphyll $a$ were centrifuged at $6,000 g_{\mathrm{n}}$ for 10 $\mathrm{min}$ and were dark adapted for $30 \mathrm{~min}$ with different concentrations of $\mathrm{Co}^{2+}$ prior to fluorescence measurements. In the case of DCMU-treated cells, DCMU (5 mmol.L $\left.\mathrm{L}^{-1}\right)$ was added and the cells incubated for $1.5 \mathrm{~min}$ before the measurements. Fluorescence spectra were recorded with spectroflurophotometer (Shimadzu, RF-510) at room temperature with a 10 $\mathrm{nm}$ excitation slit and $5 \mathrm{~nm}$ emission slit. The excitation light was monochromatic light (440 $\mathrm{nm})$ to excite chlororphyll $a$ (Gupta and Singhal, 1996).

\section{RESULTS}

Effect of $\mathrm{Co}^{2+}$ on the growth of M. minutum: Low concentrations of $\mathrm{Co}^{2+}$ led to an increase in the growth of M. minutum. Thus, 8 and $13 \%$ stimulation were observed in the cultures treated with 0.1 and $0.5 \mathrm{ppm}$, respectively, after 10 days of incubation. On the other hand, higher concentrations exerted an inhibitory effect on algal growth. Thus 5, 17 and $42 \%$ reductions were observed in the cultures treated with 1,2 and 3 ppm, respectively, after 10 days of incubation (figure 1).

Effect of cobalt on the growth of N. perminuta: Low concentrations of $\mathrm{Co}^{2+}(0.5$ and $1.5 \mathrm{ppm})$ showed a slight increase in the growth of $N$. perminuta with increase of about 5 and 9 $\%$ respectively as shown in figure 2 . On the other hand, considerable reduction in growth was observed with higher concentrations. The reductions were 14,18 and $36 \%$ below the control value after 7 days of incubation in cultures treated with $2.5,3.5$ and $5 \mathrm{ppm} \mathrm{Co}^{2+}$, respectively.

Effect of cobalt on the pigments content of M. minutum: Data presented in table 1 show that application of 0.1 and $0.5 \mathrm{ppm}$ $\mathrm{Co}^{2+}$ increased Chlorophyll $a$ content whereas higher $\mathrm{Co}^{2+}$ concentrations (1,2 and $3 \mathrm{ppm}$ ) led to significant reductions in chlorophyll $a$ biosynthesis, with values of 25,38 and $46 \%$ below the control level, respectively. A similar effect of $\mathrm{Co}^{2+}$ on chlorophyll $b$ biosynthesis was exhibited. Thus, low $\mathrm{Co}^{2+}$ concentrations increased the biosynthesis of chlorophyll $b$, while high concentrations led to reduction in its content. With

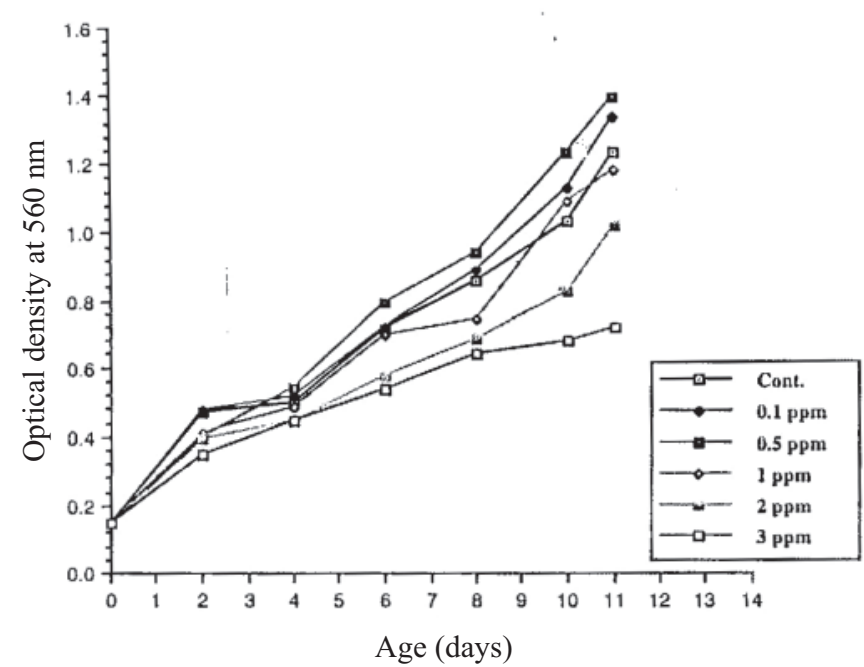

Figure 1. Effect of different $\mathrm{Co}^{2+}$ concentrations (ppm) on the growth of $M$. minutum as measured by optical density at $560 \mathrm{~nm}$.

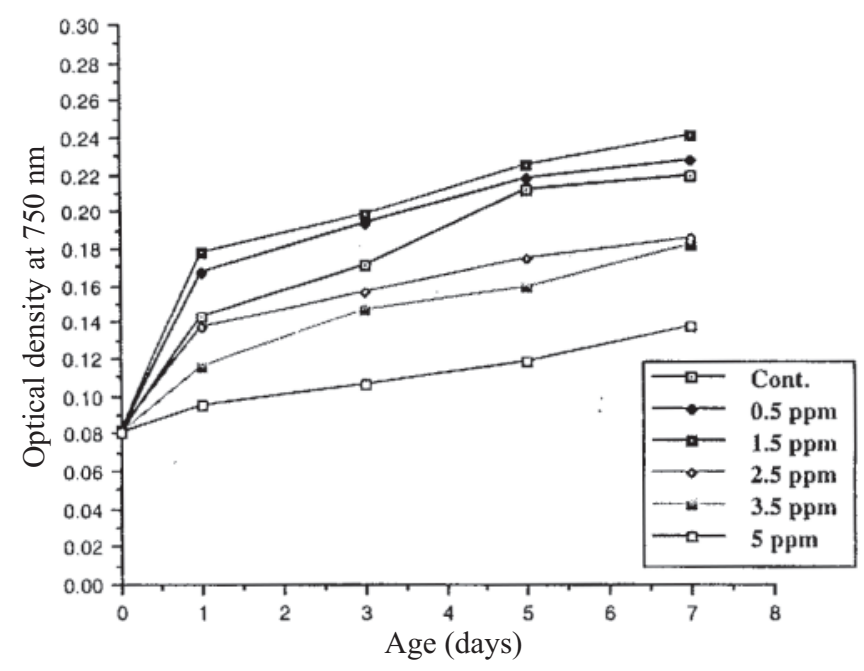

Figure2. Effect of different $\mathrm{Co}^{2+}$ concentrations (ppm) on the growth of $N$. perminuta as measured by optical density at $750 \mathrm{~nm}$.

Table 1. Effect of different concentrations of $\mathrm{Co}^{2+}$ on the pigment content of $M$. minutum after the incubation for 11 days ( $\mu \mathrm{g} \cdot \mathrm{ml}^{-1}$ algal suspension).

\begin{tabular}{lccccc}
\hline $\begin{array}{l}\mathrm{Co}^{2+} \\
(\mathrm{ppm})\end{array}$ & \multicolumn{2}{c}{ Chlorophylls } & Carotenoids & \multicolumn{2}{c}{ Chlorophylls } \\
\cline { 2 - 3 } & $a$ & $b$ & & $a+b$ & $a / b$ \\
\hline 0.0 & 8.02 & 7.05 & 2.82 & 15.07 & 1.14 \\
0.1 & 8.57 & 7.68 & 2.91 & 16.25 & 1.12 \\
0.5 & 10.35 & 9.04 & 3.02 & 19.39 & 1.14 \\
1.0 & 6.03 & 5.37 & 2.66 & 11.40 & 1.12 \\
2.0 & 4.98 & 4.28 & 2.40 & 9.26 & 1.16 \\
3.0 & 4.35 & 3.74 & 1.71 & 8.09 & 1.16 \\
\hline
\end{tabular}

chl.a: $\mathrm{F}=2.0+02 * * * ;$ carotenoids: $\mathrm{F}=2.7+03 * * * ; \mathrm{p} \leq 0.001$ 
respect to carotenoids, 0.1 and $0.5 \mathrm{ppm} \mathrm{Co}^{2+}$ stimulated their biosynthesis by 3 and $7 \%$ above the control level after 11 days of incubation, respectively. In addition, $M$. minutum was more resistant, at least to some extent, to the toxicity of $\mathrm{Co}^{2+}$. Thus 1, 2 and $3 \mathrm{ppm} \mathrm{Co}^{2+}$ resulted in 6,15 and $39 \%$ reductions in carotenoid content, respectively, compared with the control level. Moreover, 0.1 and $0.5 \mathrm{ppm} \mathrm{Co}^{2+}$ increased the total chlorophyll $(a+b)$ of M. minutum by 8 and $29 \%$ above the control value, respectively. On the other hand, a remarkable decrease in the total chlorophyll levels occurred, with reductions of 24,39 and $46 \%$ for cultures treated with 1,2

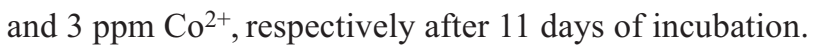

Effect of $\mathrm{Co}^{2+}$ on the pigments content of $N$. perminuta: The results shown in table 2 reveal that application of 0.5 and 1.5 ppm $\mathrm{Co}^{2+}$ increased chlorophyll $a$ content by 4 and $12 \%$ above the control level, respectively. However, chlorophyll $a$ decreased significantly with the increase in $\mathrm{Co}^{2+}$ concentrations. Thus, $2.5,3.5$ and 5 ppm led to 4,29 and $36 \%$ reductions below the control level, respectively, at the end of the incubation period. With respect to carotenoids they appeared to be more resistant to $\mathrm{Co}^{2+}$ phytotoxicity than chlorophyll $a$. Thus, the lower $\mathrm{Co}^{2+}$ concentrations ( 0.5 and $1.5 \mathrm{ppm}$ ) stimulated the biosynthesis of carotenoids. On the other hand, higher $\mathrm{Co}^{2+}$ concentrations resulted in lower reductions in carotenoids compared with chlorophyll $a$, except for $2.5 \mathrm{ppm}$ which led to a higher reduction in carotenoids than in chlorophyll $a$. The magnitude of reduction was 16 and $28 \%$ for the cultures treated with 3.5 and $5 \mathrm{ppm} \mathrm{Co}^{2+}$, respectively.

Table 2. Effect of different concentrations of $\mathrm{Co}^{2+}$ on the pigment content of $N$. perminuta after the incubation for 7 days ( $\mu \mathrm{g} \cdot \mathrm{ml}^{-1}$ algal suspension).

\begin{tabular}{lccc}
\hline $\begin{array}{l}\mathrm{Co}^{2+} \\
(\mathrm{ppm})\end{array}$ & Chl. $a$ & Carotenoids & Chl. $a /$ carotenoids \\
\hline 0.0 & 2.50 & 3.08 & 0.81 \\
0.5 & 2.61 & 3.18 & 0.82 \\
1.5 & 2.81 & 3.57 & 0.79 \\
2.5 & 2.40 & 2.77 & 0.87 \\
3.5 & 1.78 & 2.59 & 0.69 \\
5.0 & 1.60 & 2.22 & 0.72 \\
\hline
\end{tabular}

chl.a: $F=1.2^{+02 * * *}$; carotenoids: $F=6.3^{* * *} ; \mathrm{p} \leq 0.001$

Effect of different concentrations of $\mathrm{Co}^{2+}$ on the photosynthetic $\mathrm{O}_{2}$ evolution and respiration of M. minutum: Table 3 shows that low concentrations of $\mathrm{Co}^{2+}(0.1$ and $0.5 \mathrm{ppm})$ generally stimulated $\mathrm{O}_{2}$ evolution and dark respiration through- out the experimental period (11 d). The maximum stimulations in $\mathrm{O}_{2}$ evolution (59\%) and dark respiration (76\%) were recorded on the 10th and 11th days, respectively, for cultures treated with $0.5 \mathrm{ppm} \mathrm{Co}^{2+}$, in comparison with the control. Photosynthetic activity of M. minutum showed progressive reductions in response to treatment with higher cobalt concentrations (1, 2 and $3 \mathrm{ppm})$ during the cultivation period except in the case of the 10th day of the culture treated with $1 \mathrm{ppm} \mathrm{Co}^{2+}$, which produced the same amount of $\mathrm{O}_{2}$ evolved as control culture (table 3 ). The greatest reduction in $\mathrm{O}_{2}$ evolution was $58 \%$, recorded in the culture treated with $3 \mathrm{ppm}$ $\mathrm{Co}^{2+}$, on the 8 th day of incubation. With regard to respiration, higher $\mathrm{Co}^{2+}$ concentrations $(1,2$ and $3 \mathrm{ppm})$ led to greater reductions compared with $\mathrm{O}_{2}$ evolution. The maximum inhibition value was recorded on the 11th day in the culture treated with 3 ppm $\mathrm{Co}^{2+}$, with a value of $63 \%$ below the control level.

Effect of different concentrations of $\mathrm{Co}^{2+}$ on the photosynthetic $\mathrm{O}_{2}$ evolution and respiration of $N$. perminuta: Data presented in table 4 show that low concentrations of $\mathrm{Co}^{2+}$ ( 0.5 and $1.5 \mathrm{ppm}$ ) stimulated the $\mathrm{O}_{2}$ evolution of $N$. perminuta. The most pronounced stimulation of $\mathrm{O}_{2}$ evolution ( $51 \%$ ) was recorded on the 3 rd day in cultures treated with $1.5 \mathrm{ppm} \mathrm{Co}^{2+}$. On the other hand, application of higher $\mathrm{Co}^{2+}$ concentrations $(2.5,3.5$ and $5 \mathrm{ppm})$ resulted in pronounced reductions in $\mathrm{O}_{2}$ evolution. The maximum reduction was recorded in culture treated with $5 \mathrm{ppm} \mathrm{Co}^{2+}$ on the 5 th day of treatment, with a value of $54 \%$ below the control level.

With regard to respiration, $N$. perminuta generally showed a progressive reduction of $\mathrm{O}_{2}$ uptake in response to the increase in $\mathrm{Co}^{2+}$ concentrations, except on the 1 st day of the incubation period, where $\mathrm{O}_{2}$ uptake decreased with increasing $\mathrm{Co}^{2+}$ concentrations up to $2.5 \mathrm{ppm}$. However, $\mathrm{O}_{2}$ uptake was at the control level in the case of 3.5 and $5 \mathrm{ppm} \mathrm{Co}^{2+}$. The maximum reduction value, $38 \%$, was recorded on the 5 th day for the culture treated with $5 \mathrm{ppm} \mathrm{Co}^{2+}$. High concentrations of $\mathrm{Co}^{2+}$ had a more inhibitory effect on $\mathrm{O}_{2}$ evolution than respiration.

Effect of $\mathrm{Co}^{2+}$ on chlorophyll a a fluorescence emission spectrum of algal cells: The cells of M. minutum treated with 0.1 ppm $\mathrm{Co}^{2+}$ exhibited a slight (5.5\%) increase in fluorescence intensity. On the other hand, cultures treated with $3 \mathrm{ppm} \mathrm{Co}^{2+}$ showed a decrease in fluorescence intensity of $9.2 \%$ (figure

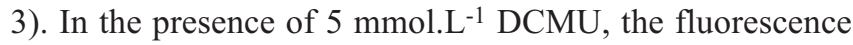
emission increased markedly. However, cultures treated with 
Table 3. Effect of different $\mathrm{Co}^{2+}$ concentrations on photosynthetic activity $\left(\mathrm{O}_{2}\right.$ evolution calculated as $\mu \mathrm{mol} \mathrm{O}_{2} \cdot \mathrm{mg}$ chlorophyll $\left.\mathrm{l}^{-1} \cdot \mathrm{h}^{-1}\right)$ and dark respiration $\left(\mathrm{O}_{2}\right.$ uptake calculated as $\left.\mu \mathrm{mol} \mathrm{O}_{2} \cdot \mathrm{h}^{-1}\right)$ of M. minutum.

\begin{tabular}{|c|c|c|c|c|c|c|c|c|c|c|c|c|}
\hline \multirow[b]{3}{*}{ Days } & \multicolumn{12}{|c|}{$\mathrm{Co}^{2+}(\mathrm{ppm})$} \\
\hline & \multicolumn{2}{|c|}{ Control } & \multicolumn{2}{|c|}{0.1} & \multicolumn{2}{|c|}{0.5} & \multicolumn{2}{|c|}{1.0} & \multicolumn{2}{|c|}{2.0} & \multicolumn{2}{|c|}{3.0} \\
\hline & O2 evol. & O2 upt. & O2 evol. & $\mathrm{O} 2$ upt. & O2 evol. & $\mathrm{O} 2$ upt. & O2 evol. & $\mathrm{O} 2$ upt. & O2 evol. & $\mathrm{O} 2$ upt. & O2 evol. & $\mathrm{O} 2$ upt. \\
\hline 2 & 267 & 1.04 & 294 & 1.04 & 359 & 1.19 & 245 & 0.89 & 151 & 0.89 & 163 & 0.89 \\
\hline 4 & 245 & 1.19 & 275 & 1.48 & 301 & 1.78 & 218 & 1.04 & 197 & 1.04 & 125 & 0.89 \\
\hline 6 & 215 & 0.89 & 245 & 1.04 & 319 & 1.19 & 190 & 0.59 & 165 & 0.44 & 109 & 0.44 \\
\hline 8 & 210 & 0.89 & 240 & 0.89 & 240 & 1.19 & 180 & 0.59 & 156 & 0.59 & 89 & 0.44 \\
\hline 10 & 191 & 1.04 & 247 & 1.19 & 303 & 1.48 & 191 & 0.89 & 160 & 0.59 & 97 & 0.59 \\
\hline 11 & 175 & 0.59 & 203 & 0.89 & 225 & 1.04 & 162 & 0.44 & 117 & 0.44 & 93 & 0.22 \\
\hline \multicolumn{13}{|c|}{$* * * \mathrm{P} \leq 0.001$} \\
\hline \multicolumn{3}{|c|}{$F$-value: } & \multicolumn{2}{|c|}{$\left(\mathrm{O}_{2}\right.$ evolution $)$} & \multicolumn{2}{|c|}{$F$-value: } & \multicolumn{2}{|c|}{$\left(\mathrm{O}_{2}\right.$ uptake $)$} & & & & \\
\hline \multicolumn{3}{|l|}{ Day } & \multicolumn{2}{|c|}{$1.7^{+02^{* * *}}$} & \multicolumn{2}{|c|}{ Day } & \multicolumn{2}{|c|}{$2.8^{+03^{* * *}}$} & & & & \\
\hline \multicolumn{3}{|c|}{ Cobalt } & \multicolumn{2}{|c|}{$8.2^{+02^{* * *}}$} & \multicolumn{2}{|c|}{ Cobalt } & \multicolumn{2}{|c|}{$4.8^{+02^{* * *}}$} & & & & \\
\hline \multicolumn{3}{|c|}{ Day x Cobalt } & \multicolumn{2}{|c|}{$1.2^{+01^{* * *}}$} & \multicolumn{2}{|c|}{ Day x Cobalt } & \multicolumn{2}{|c|}{$3.0^{+01^{* * *}}$} & & & & \\
\hline
\end{tabular}

Table 4. Effect of different $\mathrm{Co}^{2+}$ concentrations on photosynthetic activity $\left(\mathrm{O}_{2}\right.$ evolution calculated as $\mu \mathrm{mol} \mathrm{O}_{2} \cdot \mathrm{mg}$ chlorophyll $\left.{ }^{-1} \cdot \mathrm{h}^{-1}\right)$ and dark respiration $\left(\mathrm{O}_{2}\right.$ uptake calculated as $\left.\mu \mathrm{mol}_{2} \cdot \mathrm{h}^{-1}\right)$ of $N$. perminuta.

\begin{tabular}{|c|c|c|c|c|c|c|c|c|c|c|c|c|}
\hline \multirow[b]{3}{*}{ Days } & \multicolumn{12}{|c|}{$\mathrm{Co}^{2+}(\mathrm{ppm})$} \\
\hline & \multicolumn{2}{|c|}{ Control } & \multicolumn{2}{|c|}{0.5} & \multicolumn{2}{|c|}{1.5} & \multicolumn{2}{|c|}{2.5} & \multicolumn{2}{|c|}{3.5} & \multicolumn{2}{|c|}{5.0} \\
\hline & O2 evol. & O2 upt. & O2 evol. & $\mathrm{O} 2$ upt. & O2 evol. & O2 upt. & O2 evol. & $\mathrm{O} 2$ upt. & O2 evol. & O2 upt. & O2 evol. & $\mathrm{O} 2$ upt. \\
\hline 1 & 1242 & 0.89 & 1608 & 0.60 & 1788 & 0.60 & 1214 & 0.74 & 1157 & 0.89 & 939 & 0.89 \\
\hline 3 & 1376 & 2.07 & 1625 & 1.93 & 2086 & 2.07 & 1342 & 1.78 & 1213 & 1.78 & 944 & 1.63 \\
\hline 5 & 1481 & 2.37 & 1503 & 2.22 & 1531 & 2.22 & 939 & 2.07 & 827 & 2.07 & 687 & 1.48 \\
\hline 7 & 933 & 2.96 & 939 & 2.50 & 1039 & 2.82 & 822 & 2.37 & 687 & 2.37 & 617 & 1.93 \\
\hline \multicolumn{13}{|c|}{$* * * \mathrm{P} \leq 0.001$} \\
\hline \multicolumn{3}{|c|}{$F$-value: } & \multicolumn{2}{|c|}{$\left(\mathrm{O}_{2}\right.$ evolution $)$} & \multicolumn{2}{|c|}{$F$-value: } & \multicolumn{2}{|c|}{$\left(\mathrm{O}_{2}\right.$ uptake $)$} & & & & \\
\hline \multicolumn{3}{|c|}{ Day } & \multicolumn{2}{|c|}{$2.3^{+05^{* * *}}$} & \multicolumn{2}{|c|}{ Day } & \multicolumn{2}{|c|}{$5.6^{+04^{* * *}}$} & & & & \\
\hline \multicolumn{3}{|c|}{ Cobalt } & \multicolumn{2}{|c|}{$1.7^{+05^{* * *}}$} & \multicolumn{2}{|c|}{ Cobalt } & \multicolumn{2}{|c|}{$1.8^{+04^{* * *}}$} & & & & \\
\hline \multicolumn{3}{|c|}{ Day x Cobalt } & \multicolumn{2}{|c|}{$1.2^{+04^{* * *}}$} & \multicolumn{2}{|c|}{ Day x Cobalt } & \multicolumn{2}{|c|}{$2.5^{+03^{* * *}}$} & & & & \\
\hline
\end{tabular}

DCMU and $0.1 \mathrm{ppm} \mathrm{Co}^{2+}$ showed only a slight increase above the value of the DCMU-treated cells. On the other hand, culture treated with $3 \mathrm{ppm} \mathrm{Co}^{2+}$ and DCMU showed no noteworthy change in the fluorescence emission spectra compared with that of the control culture treated with DCMU alone. The cells of $N$. perminuta treated with 0.5 and $5 \mathrm{ppm} \mathrm{Co}^{2+}$ showed progressive increases in the emission spectra (14.3 and $19 \%$, respectively) compared with the control. In the presence of DCMU, cultures treated with 0.5 and $5 \mathrm{ppm} \mathrm{Co}^{2+}$ exhibited an increase in the emission spectra of chlorophyll $a$ (8.7 and $40.6 \%$, respectively) compared with the culture treated with DCMU alone (figure 4).

\section{DISCUSSION}

The present results are in agreement with those obtained by Lustigman et al. (1995) who reported that 10 and $20 \mathrm{ppm}$ $\mathrm{Co}^{2+}$ resulted in partial inhibition of growth of $C$. reinhardtii, while concentrations of $30 \mathrm{ppm}$ or higher completely prevented algal growth. In addition, El-Naggar et al. (1999) found that a lower $\mathrm{Co}^{2+}$ concentration $(0.01 \mathrm{ppm})$ stimulated growth of Nostoc muscorum, while it showed a non-significant effect on Calothrix fusca growth. However, higher $\mathrm{Co}^{2+}$ concentrations were inhibitory for both organisms. On the other hand, growth promotion at low $\mathrm{Co}^{2+}$ concentrations may be 


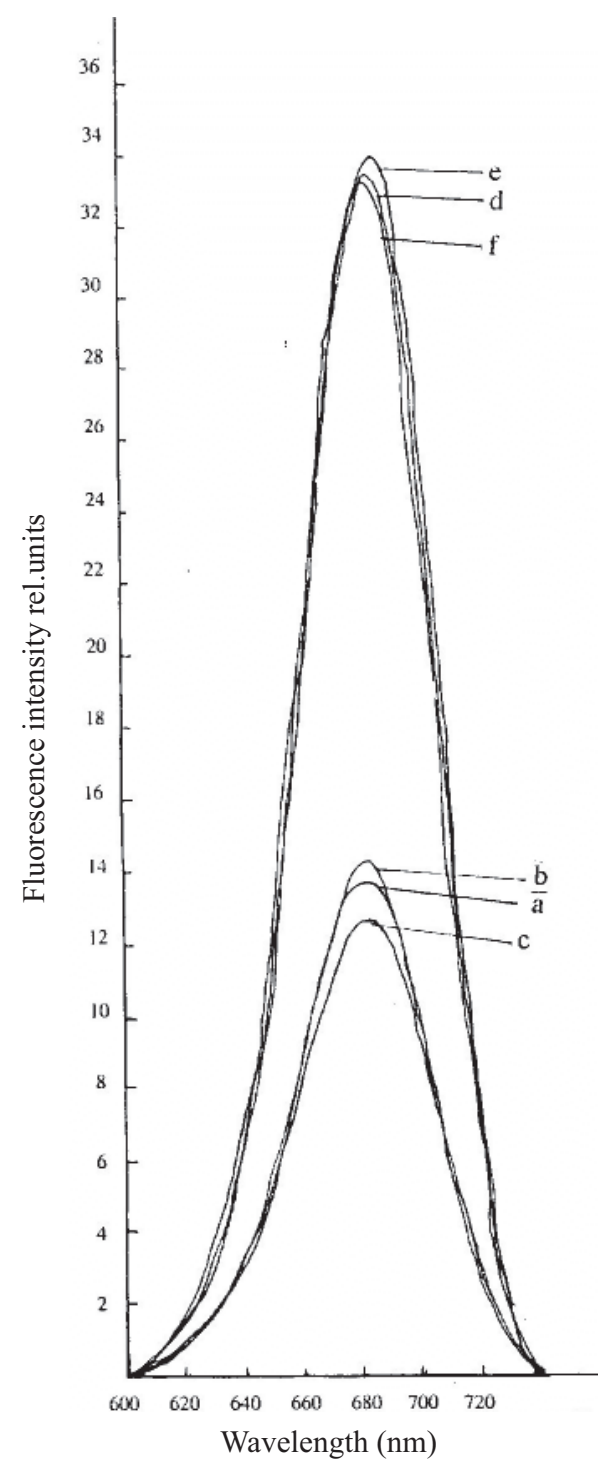

Figure 3. Fluorescence emission spectra of M. minutum treated with different cobalt concentrations for 15 min: (a) control, (b) $0.1 \mathrm{ppm} \mathrm{Co}^{2+}$, (c) $3 \mathrm{ppm} \mathrm{Co}^{2+}$, (d) DCMU alone, (e) $\mathrm{DCMU}+0.1 \mathrm{ppm} \mathrm{Co}^{2+}$, (f) $\mathrm{DCMU}+3 \mathrm{ppm} \mathrm{Co}^{2+}$.

due to $\mathrm{Co}^{2+}$ substitution for $\mathrm{Zn}^{2+}$ in some metalloenzymes in vitro and in vivo as reported by Price and Morel (1990).

The present study indicated that application of low $\mathrm{Co}^{2+}$ concentrations ( 0.1 and $0.5 \mathrm{ppm}$ ) to M. minutum cultures led to significant increases in different pigment fractions (chlorophylls $a$ and $b$, and carotenoids) reaching maximum values at the end of the incubation period for both organisms. On the other hand, progressive increases in $\mathrm{Co}^{2+}$ concentration (1, 2 and $3 \mathrm{ppm}$ ) for M. minutum caused reduction in the pigment content in a concentration-dependent fashion. Carotenoids appeared to be more resistant to $\mathrm{Co}^{2+}$ toxicity than chlorophylls $a$ and $b$. Compared with the controls a higher chlorophyll $a / b$ ratio was observed in $M$.

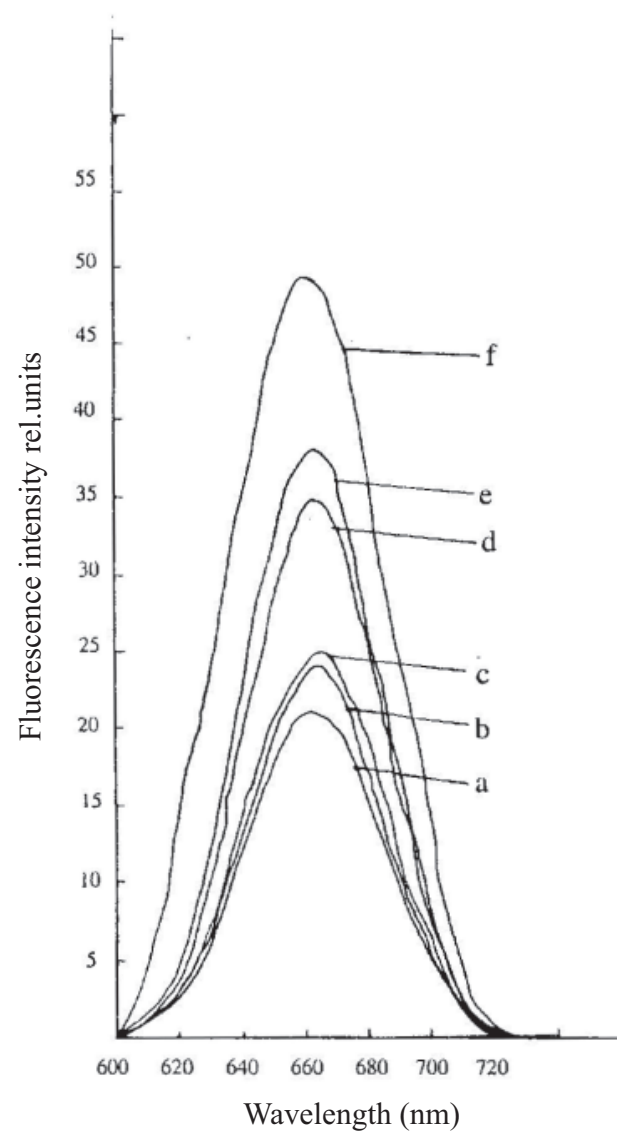

Figure 4. Fluorescence emission spectra of $N$. perminuta treated with different cobalt concentrations for 15 min: (a) control, (b) $0.5 \mathrm{ppm} \mathrm{Co}{ }^{2+}$, (c) $5 \mathrm{ppm} \mathrm{Co}^{2+}$, (d) DCMU alone, (e) $\mathrm{DCMU}+0.5 \mathrm{ppm} \mathrm{Co}^{2+}$, (f) $\mathrm{DCMU}+5 \mathrm{ppm} \mathrm{Co}^{2+}$.

minutum treated with high $\mathrm{Co}^{2+}$ concentrations due to the greater sensitivity chlorophyll $b$ compared with chlorophyll $a$ as the $\mathrm{Co}^{2+}$ concentration increased.

Our results show that lower $\mathrm{Co}^{2+}$ concentrations $(0.5$ and $1.5 \mathrm{ppm})$ led to a significant increase in chlorophyll $a$ and carotenoids of $N$. perminuta. In contrast, higher $\mathrm{Co}^{2+}$ concentrations $(2.5,3.5$ and $5 \mathrm{ppm})$ were associated with progressive reductions in pigment content. However, higher $\mathrm{Co}^{2+}$ concentrations ( 3.5 and $5 \mathrm{ppm}$ ) showed a greater inhibitory effect on chlorophyll $a$ compared with carotenoids at the end of the incubation period. These results are in agreement with those obtained by Csatorday et al. (1984), who reported inhibition of chlorophyll biosynthesis as a result of $\mathrm{Co}^{2+}$ treatment. The mechanism proposed for this inhibition is the replacement of magnesium in the chlorophyll molecule. Consequently cells accumulate protoporphyrin and synthesis of chlorophyll is blocked. In this regard, De Filippis et al. (1981) reported that reduction of chlorophyll a content is a common symptom of heavy metals toxicity. This may be attributed to 
inhibition of reduction steps in the biosynthetic pathways of the pigment.

In the present study the effect of different concentrations of $\mathrm{Co}^{2+}$ on photosynthetic $\mathrm{O}_{2}$ evolution showed a tendency towards reducing the amount of $\mathrm{O}_{2}$ evolved by each alga in response to $\mathrm{Co}^{2+}$. However, an increase in $\mathrm{O}_{2}$ evolution by M. minutum and $N$. perminuta was observed at relatively low $\mathrm{Co}^{2+}$ concentrations throughout the incubation period. The magnitude of the inhibitory action was found to increase with higher metal concentrations.

At 2 and $3 \mathrm{ppm} \mathrm{Co}^{2+}$ the degree of inhibition of $\mathrm{O}_{2}$ evolution for M. minutum was greater than for N. perminuta, indicating that photosynthetic electron transport in $M$. minutum is more sensitive to $\mathrm{Co}^{2+}$ toxicity. These results are in agreement with those of El-Naggar et al. (1999) who found that low $\mathrm{Co}^{2+}$ concentration increased both $\mathrm{O}_{2}$ evolution and dark respiration in two cyanobacterial species, C. fusca and $N$. muscorum, whereas higher concentrations were inhibitory. Further confirmation of our results can be found in the data of Tiwari and Mohanty (1996) who reported that Synechocystis PCC 6803 cell growth in a medium containing 10 mmol.L-1 $\mathrm{CoCl}_{2}$ exhibited a large stimulation (50\%) of $\mathrm{O}_{2}$ evolution and an increase $(\sim 30 \%)$ in photosynthetic electron transport. With regard to the observed inhibition as a result of the addition of higher concentrations of $\mathrm{Co}^{2+}$, ElSheekh and Hammouda (1992) reported that 25 and 50 mmol.L ${ }^{-1} \mathrm{Co}^{2+}$ inhibited $\mathrm{O}_{2}$ evolution of Chlorella minutissima by 58.3 and $70.3 \%$, respectively.

With regard to the effects of various levels of $\mathrm{Co}^{2+}$ on respiration, the results obtained show that higher $\mathrm{Co}^{2+}$ concentrations have an inhibitory effect on $\mathrm{O}_{2}$ uptake by the two algal species. Low $\mathrm{Co}^{2+}$ concentrations stimulated $\mathrm{O}_{2}$ uptake of $M$. minutum throughout the experimental period. With respect to $N$. perminuta, different concentrations of $\mathrm{Co}^{2+}$ caused inhibition of $\mathrm{O}_{2}$ uptake throughout the incubation period. From the above-mentioned results, it is noteworthy that the effect of heavy metals on respiration is concentration and species dependent.

Changes in chlorophyll $a$ fluorescence intensity at room temperature are intimately associated with PSII activity and they reflect the redox states of Q, the primary acceptor of PSII (Goedheer, 1972; Renger and Schreiber, 1986). These changes play an important role in localizing the sites of primary damage of PSII (Schmidt et al., 1990). With regard to M. minutum and $N$. perminuta, the results show that low concentrations of $\mathrm{Co}^{2+}$ increased the fluorescence intensity in DCMU-treated and untreated cells. This increase was accom- panied by increasing $\mathrm{O}_{2}$ evolution in the case of DCMU-untreated cells. These results suggest that low concentrations of $\mathrm{Co}^{2+}$ stimulate electron transport at the donor side of PSII. Our results are in agreement with those reported by Tiwari and Mohanty (1996) who observed that Synechocystis cells grown in a medium containing $10 \mathrm{mmol} \cdot \mathrm{L}^{-1} \mathrm{CoCl}_{2}$ showed a large stimulation (50\%) of $\mathrm{O}_{2}$ evolution and an overall increase $(\sim 30 \%)$ in the rate of photosynthetic electron transport resulting from a small increase (15-20\%) in the number of PSII units in $\mathrm{Co}^{2+}$-grown cells.

Further increase in $\mathrm{Co}^{2+}$ concentration increased the fluorescence intensity of $M$. minutum and $N$. perminuta cells. These results indicate that high concentrations of $\mathrm{Co}^{2+}$ inhibit the electron transport at the acceptor side of PSII in $M$. minutum and $N$. perminuta. The results concerning the effect of different concentrations of $\mathrm{Co}^{2+}$ on the electron transport of the two algae studied here are in agreement with those of Baker et al. (1982) and Mohanty et al. (1989), who reported that the effect of $\mathrm{Co}^{2+}, \mathrm{Ni}^{2+}$ or $\mathrm{Zn}^{2+}$ is possibly due to their role in modifying the function of $\mathrm{Q}_{\mathrm{B}}$, thereby impairing the PSII activity. $\mathrm{Co}^{2+}, \mathrm{Ni}^{2+}$ or $\mathrm{Zn}^{2+}$ can impair the $\mathrm{Q}_{\mathrm{B}}$ function in three possible ways. Interruption of electron flow between $Q_{A}$ and $Q_{B}$ directs modification of $Q_{B}$ or alteration of components beyond $\mathrm{Q}_{\mathrm{B}}$, which leads to the impairment of PSII activity at the $\mathrm{Q}_{\mathrm{B}}$ site.

\section{REFERENCES}

Allen MM and Stanier ST (1968) Selective isolation of blue green algae from water and soil. J. Gen. Microbiol. 51: 203.

Baker NR, Fernyhough P and Meek IT (1982) Light dependent inhibition of photosynthetic electron transport by zinc. Physiol. Plant. 56:217-222.

Csatorday K, Gombos Z and Szalontai B (1984) Manganese and cobalt toxicity in chlorophyll biosynthesis. Proc. Nat. Acad. Sci. USA 81:476-478.

Custodio E (1992) Ground water pollution in Spain: General aspects. J. IWEM. 211:542-548.

Czerpak R, Bajguz A, Chodkowski K and Popow H (1994) Influence of nickel and cobalt on the growth and biochemical changes of Chlorella pyrenoidosa (Chlorophyceae). Pol. Arch. Hydrobiol. 41:161-169.

De-Filippis LF, Hampp R and Ziegler H (1981) The effects of sublethal concentrations of zinc, cadmium and mercury on Euglena growth and pigments. Z. Pflanzen. Physiol. 101:37-47.

El-Naggar AH, Osman MEH, Dyab MA and El Mohsenawy EA (1999) Cobalt and lead toxicities on Calothrix fusca and Nostoc muscorum. J. Union Arab biol. Cairo 7:421-441. 
El-Sheekh MM and Hammouda OHE (1992) Effect of cobalt stress on the photosynthetic electron transport activity and protein synthesis in the green alga Chlorella minutissima. Bull. Fac. Sci. Mansoura Univ. 19:85-97.

Gadd GM and Griffiths AJ (1978) Microorganisms and heavy metal toxicity. Microb. Ecol. 4:303-317.

Goedheer JC (1972) Fluorescence in relation to photosynthesis. Ann. Rev. Plant Physiol. 23:87-112.

Gupta AB and Singhal GS (1996) Effect of heavy metals on phycobiliproteins of Anacystis nidulans. Photosynthetica 32:545-548.

Kuhl A (1962) Zur physiologie der speicherung kondensetem organischer phosphate in Chlorella. In: Beiträge zur Physiologie und Morphologie der Algen. Gustav Fischer Verlage. Stuttgart. West Germany.

Lu CM, Chau CW and Zhang JH (2000) Acute toxicity of excess mercury on the photosynthetic performance of cyanobacterium, S. platensis-assessment by chlorophyll fluorescence analysis. Chemosphere 41:191-196.

Lustigman B, Lee LH and Weiss-Magasic C (1995) Effect of cobalt and $\mathrm{pH}$ on the growth of Chlamydomonas reinhardtii. Bull. Environ. Contam. Toxicol. 55:65-72.

Magdaleno A, Gomez CE, Velez CG and Accorinti J (1997) Preliminary toxicity tests using the green alga, Ankistrodesmus falcatus. Environ.Toxicol. Water. Qual. 12:11-14.

McKinney G (1941) Absorption of light by chlorophyll solutions. J. Biol. Chem.140:315-322.

Miyachi S, Buerger J, Kotzabasis K, Thielmann J and Senger H (1996) Photosynthetic characteristics of three strains of cyanobacteria grown under low or high $\mathrm{Co}^{2+}$ conditions. Z. Natureorsch. Sect. C, 51:40-46.

Mohanty N, Vass I and Demeter S (1989) Impairment of photosystem 2 activity at the level of secondary quinone electron acceptor in chloroplasts treated with cobalt, nickel and zinc ions. Physiol. Plant. 76:386-390.

Price NM and Morel F. MM (1990) Cadmium and cobalt substitution for zinc in marine diatoms. Nature 344:656-660.

Reddy GN and Prasad MNV (1990) Heavy metal binding proteins/peptides: Occurrence, structure, synthesis and functions: A review. Environ. Exp. Bot. 30:251-264.

Reed RH and Gadd GM (1989) Metal tolerance in eukaryotic and prokaryotic algae. In: Shaw AJ (ed), Heavy metal tolerance in plants: evolutionary aspects, pp. 105-118. CRC Press, Boca Raton, Florida.

Renger G and Schreiber M (1986) Practical applications of fluorimetric methods to algae and higher plant research. In: Govindjee and Fork DC (eds), Light Emission by plants and bacteria. pp.587-619. Academic Press, New York.

Reuter W and Muller C (1993) Adaptations of the photosynthetic apparatus of cyanobacteria to light and $\mathrm{CO}_{2}$. J. Photochem. Photobiol. B: Biol. 21:3-27.

Schmidt W, Neubauer C, Kolbowski J, Schreiber M and Ubrach W (1990) Comparison of effects of air pollutants $\left(\mathrm{SO}_{2}, \mathrm{O}_{3}, \mathrm{NO}_{2}\right)$ in leaves by measurements of chlorophyll fluorescence and $\mathrm{P}_{700}$ absorbance changes. Photosynth. Res. 25:241-248.

Sriharan S, Bagga D and Sriharan T P (1990) Effects of nutrients and temperature on lipid and fatty acid production in the diatom Hantzschia DI - 60 . Appl. Biochem. Biotec. 24/25:309-326.

Tiwari S and Mohanty P (1993) Cobalt chloride induced stimulation of photosystem II electron transport in Synechocystis PCC 6803 cells. Photosynth. Res. 38:463469.

Tiwari S and Mohanty P (1996) Cobalt induced changes in photosystem activity in Synechocystis PCC 6803: Alterations in energy distribution and stoichiometry. Photosynth. Res. 50:243-256.

Tripathy BC, Bhatia B and Mohanty P (1981) Inactivation of chloroplast photosynthetic electron- transport activity by $\mathrm{Ni}^{2+}$. Biochim. Biophys. Acta 638:217-224.

Tripathy BC, Bhatia B and Mohanty P (1983) Cobalt ions inhibit electron-transport activity of photosystem II without affecting photosystem I. Biochim. Biophys. Acta 722:88-93.

Wetherel DF (1961) Culture of fresh water algae in enriched natural sea water. Physiol Plant. 14:1-6. 